\title{
Use of Ultrasound Bath in the Extraction and Quantification of Ester-Linked Phenolic Acids in Tropical Forages
}

\author{
Mellina Damasceno Rachid Santos ${ }^{1}$, Aline de Paula Vitor ${ }^{1}$, Jailton da Costa Carneiro², \\ Domingos Sávio Campos Paciullo ${ }^{2}$, Renato Camargo Matos ${ }^{1}$, Maria Auxiliadora Costa Matos ${ }^{{ }^{*}}$ \\ ${ }^{1}$ NUPIS (Núcleo de Pesquisa em Instrumentação e Separação Analíticas), Departamento de Química, Instituto de \\ Ciências Exatas, Universidade Federal de Juiz de Fora, Juiz de Fora, Brazil \\ ${ }^{2}$ EMBRAPA—Centro Nacional de Pesquisa de Gado de Leite (CNPGL), Juiz de Fora, Brazil \\ E-mail: maria.auxiliadora@ufjf.edu.br \\ Received March 29, 2011; revised May 12, 2011; accepted May 20, 2011
}

\begin{abstract}
A method was developed for the analysis of ester-linked phenolic acids in forage samples using extraction by an ultrasound-assisted treatment and quantification by HPLC with a UV-VIS detector. A reversed-phase C18 column was used for developing the method and the optimal condition was established with isocratic elution using acetonitrile/methanol/ $\mathrm{H}_{3} \mathrm{PO}_{4} \mathrm{pH} 2.08$ (13:12.5:74.5) as the mobile phase. To reduce the time of sample processing, the extraction of ester-linked phenolic acids was studied using ultrasound bath and the results were then compared with those from an extraction usual using alkaline hydrolysis $\left(20^{\circ} \mathrm{C}\right.$ for $\left.24 \mathrm{~h}\right)$. The method was valued through external and internal calibration. Internal calibration using o-coumaric acid as internal standard and m-coumaric acid as surrogate internal standard showed better results. The detection limits were of 0.09 and $0.04 \mathrm{mg} \cdot \mathrm{L}^{-1}$ for p-coumaric and ferulic acids, respectively. The proposed method showed a good linear dynamic range $\left(3.00-30.00 \mathrm{mg} \cdot \mathrm{L}^{-1}\right)$ for the analytes. The usefulness of the method- ology was demonstrated by addition-recovery experiments using forage samples and values were in the 83 to $99 \%$ range. The extraction of ester-linked phenolic acids by 120 minutes of ultrasound bath was faster and more reproducible than alkaline hydrolysis $\left(20^{\circ} \mathrm{C}\right.$ for $\left.24 \mathrm{~h}\right)$.
\end{abstract}

Keywords: Ultrasound Bath, Phenolic Acids, Forage, Internal Calibration

\section{Introduction}

Phenolic compounds are a group of secondary metabolites synthesized by plants during development as a defense against pathogenic ingress, wounding and UV radiation $[1,2]$. Among the main phenolic compounds present in plants are phenolic acids, such as ferulic acid, pcoumaric acid and caffeic acid.

These acids are present in plants in both free and bound forms where a small fraction occurs as "free acids" and the majority are linked to structural components of the plant [3,4]. According to Jung (1989), ferulic and p-coumaric acids seem to be generally esterified to different components of the cell wall. The majority of pcoumaric acid are esterified to lignin whereas ferulic acid tends to associate with the hemicellulose fraction and may form a cross-linkage between lignin and hemicellu- lose $[3,4]$. Due to such associations, several studies have shown that these compounds potentially affect the digestibility of forages by the rumen, thereby compromising livestock performance [3,5-10].

Acidic hydrolysis and alkaline hydrolysis are the most common means of releasing the phenolics acids [2]. The main method of extraction applied in forage samples is alkaline hydrolysis. It allows quantification of total phenolic acids (ester-linked and ether-linked) or those that are only ester-linked through two types of treatment: mild alkaline or hot alkaline hydrolysis [11]. In the mild alkaline extraction, where the sample is treated with $\mathrm{NaOH} 1 \mathrm{~mol} \cdot \mathrm{L}^{-1}$ solution at $20^{\circ} \mathrm{C}$ for $24 \mathrm{~h}$, only ester bonds are cleaved. During hot alkaline hydrolysis, the sample is usually treated with a solution of $\mathrm{NaOH} 4$ $\mathrm{mol} \cdot \mathrm{L}^{-1}$ at $170^{\circ} \mathrm{C}$ for $2 \mathrm{~h}$, and both ester and ether bonds are cleaved. The ether-linked derivatives are estimated 
by the difference between total phenolic acids and the ester-linked molecules [4,7].

Phenolic compounds have been analyzed in different samples by capillary electrophoresis (CE) [12-15], gas chromatography equipped with a mass spectrometric detector (GC-MS) [16-20], ultra performance liquid chromatography (UPLC) [21] and high performance liquid chromatography (HPLC) [3,5-7,9,20-27]. HPLC is most frequently used because it does not require a derivatization sample for analysis as gas chromatography [24]. When compared to capillary electrophoresis, HPLC is better in terms of accuracy, sensitivity and precision although it consumes more solvent and time for sample treatment [15].

Recently, ultrasound bath has been used as an ancillary tool for traditional extraction methods due to the simplicity of the method and a decrease in the time needed for extraction. There have been many studies applying ultrasound bath in the sample treatment of soils and sediments [28-31], biological [32-34], nutritious [35, 36]. However, in the case of forage samples, no study has yet been reported in the literature describing this technique for the extraction and quantification of phenolic acids.

The objective of this work was to propose an alternative method that is fast and precise for extracting esterlinked phenolic acids using an ultrasound bath. This paper describes the development of a new method using high performance liquid chromatography (HPLC-UV) for the separation of five phenolic acids (ferulic, p-coumaric, m-coumaric, o-coumaric and caffeic acids). Shikimic acid was also included in the calibrations and is an organic acid that occurs as an intermediate during the process of hydroxycinnamic acid formation $[3,37]$. The performance of the analytical procedure was evaluated by determining the concentration of phenolic acids in forage samples.

\section{Experimental}

\subsection{Chemicals and Solutions}

The standard compounds (including ferulic, p-coumaric, m-coumaric, o-coumaric, caffeic and shikimic acids) were purchased from Sigma-Aldrich (St. Louis, MO, USA). HPLC grade solvents (methanol, acetonitrile and tetrahydrofuran) and HPLC grade reagents (phosphoric acid, acetic acid and potassium phosphate monobasic) were from Tedia Company Inc. (Fairfield, OH, USA). The chemicals sodium acetate, sodium hydroxide and hydrochloric acid were from Vetec (Rio de Janeiro, RJ, Brazil).

Stock solutions of the ferulic, p-coumaric, m-coumaric, o-coumaric, caffeic and shikimic acids were prepared at a concentration of $1 \mathrm{~g} \cdot \mathrm{L}^{-1}$ in methanol and filtered thr- ough a $0.45 \mu \mathrm{m}$ PTFE filter. These solutions were stable for one week when stored at $4^{\circ} \mathrm{C}$.

\subsection{Preparation of Calibration Standards}

Standard solution containing a mixture of caffeic, shikimic, ferulic and p-coumaric acids were first prepared in mobile phase at a concentration of $100 \mathrm{mg} \mathrm{L}^{-1}$ and were gradually diluted in mobile fase to working concentrations of 3 to $20 \mathrm{mg} \cdot \mathrm{L}^{-1}$. An internal standard of o-coumaric acid and a surrogate internal standard of m-coumaric acid was added to set up a resulting concentration of $10 \mathrm{mg} \cdot \mathrm{L}^{-1}$ in all standard solutions.

\subsection{HPLC Apparatus}

HPLC analyses were conducted using an Agilent 1100 Series system equipped with a manual injection valve with a $20 \mu \mathrm{L}$ sample loop, a degasser system, a quartet pump and a multiple wavelength UV-detector. Data acquisition and processing were accomplished with the Agilent Chemistation LC Systems software. A reversedphase (RP) column ZORBAX ODS (150.0 mm $\times 4.6$ $\mathrm{mm}$ I.D., $5 \mu \mathrm{m}$ particle size) and a ZORBAX ODS pre-column (12.5 mm × $4.6 \mathrm{~mm}$ I.D., $5 \mu \mathrm{m}$ particle size) were used at room temperature.

\subsection{Optimization of the Chromatographic Separation}

This study involved the optimization of the separation conditions of shikimic, caffeic, p-coumaric and ferulic acids using a mobile phase composed for organic solvents and acid solution or buffer. Initially, mixtures of methanol, acetonitrile or tetrahydrofuran with aqueous solution were tested as eluents to obtain a sufficient resolution. The $\mathrm{pH}$ range of the eluent (2.08 to 4.50) was adjusted with phosphoric acid, acetic acid, acetate buffer or phosphate buffer. The values of retention time, peak symmetry, resolution and sensitivity were evaluated for sufficient resolution on the RP- column.

\subsection{Plant Material}

Fractions of stem and leaf of the species Brachiaria brizantha Marandu, Cynodon dactylon Florakirk, Cynodon nlemfuensis Florona, Panicum maximum Mombaça, Pennisetum purpureum Anão and Pennisetum pur- pureum Pioneiro were obtained from the experimental farm of EMBRAPA (Goiás, Brazil). The samples were taken every 30 days, dried in forced air oven at $55^{\circ} \mathrm{C}$ for 
Table 1. Content (mg $\mathrm{g}^{-1}$ dry matter) of ester-linked p-coumaric and ferulic acids in Panicum maximum Mombaça extracted in bath with programmed temperature (at $20^{\circ} \mathrm{C}$ for $24 \mathrm{~h}$ ) and ultrasound (at room temperature for $120 \mathrm{~min}$ ).

\begin{tabular}{|c|c|c|c|c|}
\hline \multirow[b]{3}{*}{ Replicate } & \multicolumn{4}{|c|}{ Content (mg $\cdot \mathrm{g}^{-1}$ dry matter) } \\
\hline & \multicolumn{2}{|c|}{ Bath with programmed temperature } & \multicolumn{2}{|c|}{ Ultrasound } \\
\hline & $\mathrm{p}-\mathrm{CA}$ & FA & $\mathrm{p}-\mathrm{CA}$ & FA \\
\hline 1 & 4.48 & 4.75 & 4.08 & 4.93 \\
\hline 2 & 4.39 & 4.52 & 4.09 & 4.93 \\
\hline 3 & 4.20 & 4.42 & 4.05 & 4.88 \\
\hline Sd & 0.14 & 0.17 & 0.03 & 0.03 \\
\hline RSD & 3 & 3 & 1 & 1 \\
\hline
\end{tabular}

p-CA = Ester-Linked p-Coumaric Acid; FA = Ester-Linked Ferulic Acid; Sd = standard deviation; RSD = relative standard deviation.

$72 \mathrm{~h}$ and grounded $(1 \mathrm{~mm})$.

\subsection{Extraction of Ester-Linked Phenolic Acids}

Approximately $25.0 \mathrm{mg}$ of leaf of Panicum maximum Mombaça were extracted at room temperature with 1 $\mathrm{mol} \cdot \mathrm{L}^{-1} \mathrm{NaOH}$ using the following times for sonication: 15, 30, 60, 90, 120, 150, 180, 210, 240, 270 and $300 \mathrm{mi}-$ nutes. The results obtained were then compared with those from the alkaline hydrolysis at $20^{\circ} \mathrm{C}$ for $24 \mathrm{~h}$. Triplicate extractions and analyses were carried out.

After extraction, the samples were subsequently filtered and washed with water. The combined filtrate and wash was acidified to $\mathrm{pH} 2.5$ with $6 \mathrm{~mol} \cdot \mathrm{L}^{-1} \mathrm{HCl}$ and brought to a final volume of $10 \mathrm{~mL}$. The sample solutions were diluted using mobile phase, filtered through a $0.45 \mu \mathrm{m}$ PTFE filter and analyzed by HPLC. The injection volume was $20 \mu \mathrm{L}$.

\section{Results and Discussion}

\subsection{Development of the HPLC Method}

Preliminary tests employing a binary mixture (organic solvent: aqueous solution) as the mobile phase were performed. The best isocratic separation was established for each organic solvent (acetonitrile, methanol and tetrahydrofuran) at different $\mathrm{pH}$ values (2.08, 2.20, 2.50, 3.00, $3.50,4.00$ and 4.55). This showed that increasing $\mathrm{pH}$ resulted in a longer retention time of the compounds. Depending on the eluent $\mathrm{pH}$, the ferulic and p-coumaric acids present double peaks at higher $\mathrm{pH}$ values. This can be explained by the presence of weak organic acids, with pKa values of around 4.5 and 9.5 [17]. The best results were obtained with the mobile phase adjusted to $\mathrm{pH} 2.08$ with phosphoric acid (for all three solvents) because ionization of the phenolic acids is suppressed at this $\mathrm{pH}$ value. However, $\mathrm{pH}$ variations of the eluent using binary compositions did not improve the resolution. Among the compositions of the mobile phase optimized by applying the ternary mixture of solvents, the best separation condition was for isocratic elution with a mobile phase composed of acetonitrile/methanol/ $\mathrm{H}_{3} \mathrm{PO}_{4} \mathrm{pH} 2.08$ (13: 12.5:74.5) at a flow of $1 \mathrm{~mL} \cdot \mathrm{L}^{-1}$. The detection of the compounds was based on different wavelengths that took into consideration their maximum absorption. Here, the signal was registered at $236 \mathrm{~nm}$ from 0 to 3 minutes, 316 $\mathrm{nm}$ from 3 to 9.1 minutes and $236 \mathrm{~nm}$ from 9.1 to 15 minutes. This detection had increased sensitivity, improving the detection and quantification limits of the method.

\subsection{Extraction of Ester-Linked Phenolic Acids}

For ultrasound bath extraction, analyses were performed in three replicates. Sonication times of 90 minutes and less were not enough to extract completely the esterlinked phenolic acids. The peak areas of the phenolic acids increased with increasing time and reached their maxima at 120 minutes of sonication. At sonication times over 150 minutes, the peak areas decreased, indicating a possible compound degradation.

To evaluate accuracy, paired Student's t-test was used to determine whether significant differences existed between results obtained using 120 minutes of sonication in an ultrasound bath and those obtained by alkaline hydrolysis extraction $\left(20^{\circ} \mathrm{C}\right.$ for $\left.24 \mathrm{~h}\right)$. The paired Student's ttest $(\alpha=0.05)$ showed that there was not a significant difference between the means. However, results from extraction employing the ultrasound bath presented smaller relative standard deviations, indicating that this method is more reproducible when compared to alkaline hydrolysis (Table 1). Therefore, extraction with ultrasound bath for 120 minutes was used to reduce the time of sample analysis.

\subsection{Features of the Analytical Method}

The evaluation of the method was performed by external 


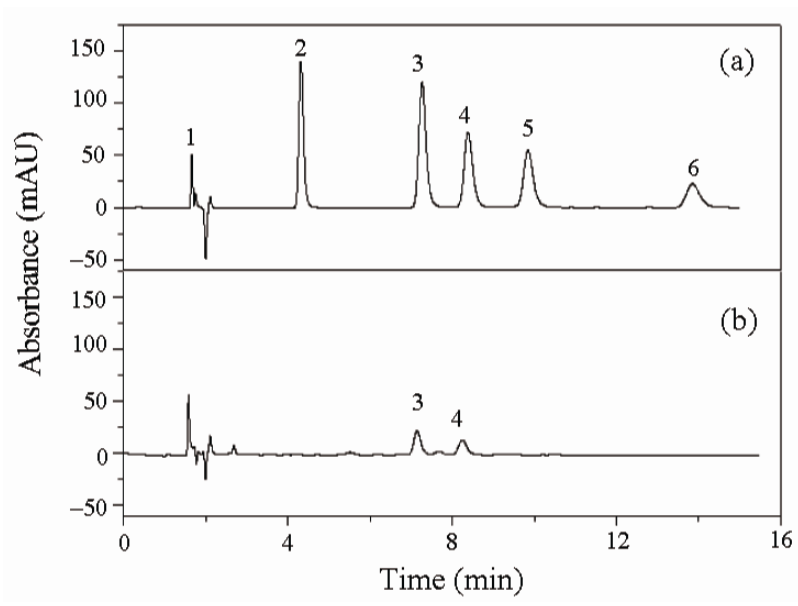

Figure 1. Typical chromatograms of (a) standard mixture and (b) phenolic acids released from ester bonds in a sample of Panicum maximum Mombaça leaf. Peaks: 1) shikimic acid, 2) caffeic acid, 3) p-coumaric acid, 4) ferulic acid, 5) m-coumaric acid, and (6) o-coumaric acid. Analytical conditions: column, ZORBAX ODS; flow-rate, $1.0 \mathrm{ml} / \mathrm{min}$; detection for programming of wavelength; mobile phase, acetonitrile/methanol/ $\mathrm{H}_{3} \mathrm{PO}_{4} \mathrm{pH}=2.08$ (13:12.5:74.5).

and internal calibration. Initially was studied the application of the o-coumaric and m-coumaric acids as internal standard and surrogate internal standard. Preliminary was studied the presence of o-coumaric and m-coumaric acids in forage samples. Figure 1 compares the chromatograms of a standard mixture (ferulic, p-coumaric, mcoumaric, o-coumaric, caffeic and shikimic acids) and a forage sample. The retention time obtained for the compounds confirmed that o-coumaric and m-coumaric acids were not present in the samples. As a consequence, $\mathrm{m}$ coumaric and o-coumaric acids were used as surrogate internal standard and internal standard, respectively.

The precision of the method was evaluated by repeated injection $(n=6)$ of a forage sample, and the standard deviation was determined as better than 3\% (external calibration) and 1\% (internal calibration). The sensitivity was also determined using the limit of detection (LOD) and the limit of quantification (LOQ). The LOD was calculated as $3 \mathrm{~s}$, where $\mathrm{s}$ is the average signal of standard deviation of 6 forage sample injections with low phenolic acid concentration, and the LOQ was $10 \mathrm{~s}$.

Table 2 shows the analytical parameters for repeated injection of a tropical forage sample using internal and external calibrations. The internal calibration presented smaller values of LOD, LOQ and RSD. The best results were attributed the use of the internal standard (o-coumaric acid) and surrogate standard (m-coumaric acid) that corrected fluctuations between each injection and losses during the sample extraction process, respectively.

Linearity was evaluated, taking into account the correlation coefficient (r) and the response factor in the
Table 2. Limit of detection (LOD), limit of quantification (LOQ) and repeatability achieved for external and internal calibration.

\begin{tabular}{ccccccc}
\hline & \multicolumn{3}{c}{ External calibration } & \multicolumn{3}{c}{ Internal calibration } \\
\hline $\begin{array}{c}\text { Comp } \\
\text { ound }\end{array}$ & $\begin{array}{c}\mathrm{LOD} \\
\left(\mathrm{mg} \cdot \mathrm{L}^{-1}\right)\end{array}$ & $\begin{array}{c}\mathrm{LOQ} \\
\left(\mathrm{mg} \cdot \mathrm{L}^{-1}\right)\end{array}$ & $\begin{array}{c}\mathrm{RSD} \\
(\%)\end{array}$ & $\begin{array}{c}\mathrm{LOD} \\
\left(\mathrm{mg} \cdot \mathrm{L}^{-1}\right)\end{array}$ & $\begin{array}{c}\mathrm{LOQ} \\
\left(\mathrm{mg} \cdot \mathrm{L}^{-1}\right)\end{array}$ & $\begin{array}{c}\mathrm{RSD} \\
(\%)\end{array}$ \\
p-CA & 0.18 & 0.60 & 3 & 0.09 & 0.28 & 1 \\
FA & 0.08 & 0.26 & 1 & 0.04 & 0.15 & 1 \\
\hline
\end{tabular}

p-CA = Ester-Linked $p$-Coumaric Acid; FA = Ester-Linked Ferulic Acid; $\mathrm{LOD}=$ limit of detection; $\mathrm{LOQ}=$ limit of quantification; RSD = relative standard deviation.

Table 3. Results of regression analysis on calibration.

\begin{tabular}{|c|c|c|c|c|}
\hline & \multicolumn{2}{|c|}{ External calibration } & \multicolumn{2}{|c|}{ Internal calibration } \\
\hline Compound & $\begin{array}{c}\text { regression } \\
\text { equation } y= \\
a x+b^{\mathrm{a}}\end{array}$ & $\begin{array}{l}\text { correlation } \\
\text { coefficient }\end{array}$ & $\begin{array}{c}\text { regression } \\
\text { equation } y= \\
a x+b^{b}\end{array}$ & $\begin{array}{l}\text { correlation } \\
\text { coefficient }\end{array}$ \\
\hline $\begin{array}{l}\text { Shikimic } \\
\text { acid }\end{array}$ & $\begin{aligned} y= & 17.392 x+ \\
& 3.294\end{aligned}$ & 940 & $\begin{array}{c}y=0.1987 x+ \\
0.0022\end{array}$ & 970 \\
\hline $\begin{array}{l}\text { Caffeic } \\
\text { acid }\end{array}$ & $\begin{array}{c}y=111.81 x+ \\
6.2715\end{array}$ & 95 & $\begin{array}{c}y=1.2778 x- \\
0.0026\end{array}$ & $r=0.99995$ \\
\hline $\begin{array}{c}\text { p-Coumaric } \\
\text { acid }\end{array}$ & $y=154.71 x+$ & 90 & $\begin{array}{c}y=1.768 x- \\
0.0026\end{array}$ & 0.99990 \\
\hline Ferulic acid & $\begin{array}{c}y=96.016 x+ \\
42.606\end{array}$ & $r=0.99910$ & $\begin{aligned} y & =1.0973 x \\
& +0.0399\end{aligned}$ & $r=0.99935$ \\
\hline
\end{tabular}

${ }^{a}$ Where $y$ and $x$ are the peak area (mAU) and concentration of the analytes $\left(\mathrm{mg} \cdot \mathrm{L}^{-1}\right.$ ), respectively; ${ }^{\mathrm{b}}$ Where $\mathrm{y}$ is the ration of the area of the analyte peak divided by the area of the surrogate internal standard and $x$ is the ration of the concentration of the analyte divided by the concentration of the surrogate internal standard.

concentration range of 3.00 to $30.00 \mathrm{mg} \cdot \mathrm{L}^{-1}$. Calibration curves were determined by a mixture of standard solutions of the phenolic acids, and applying an internal standard (o-coumaric acid) and a surrogate standard (mcoumaric acid). Each point on the calibration curve corresponds to an average signal from three independent peak measurements for each acid. The proportionality of peak area and concentration was confirmed for all the analytes (correlation coefficient $>0.999$ ), as shown in Table 3.

The accuracy of the method was evaluated through recovery assays using tropical forage samples spiked with a mixture of acid standards comprising ferulic, pcoumaric, m-coumaric, caffeic and shikimic acids at three fortification levels: $5.00,7.50$ and $10.00 \mathrm{mg} \cdot \mathrm{L}^{-1}$ (Table 4) with $10.00 \mathrm{mg} \cdot \mathrm{L}^{-1}$ o-coumaric acid as the internal standard. A blank spike $\left(\mathrm{NaOH} 1 \mathrm{~mol} \cdot \mathrm{L}^{-1}\right)(n=$ 5) was also prepared for the extraction tests with a mixture of the phenolic acids at a concentration of 10.00 $\mathrm{mg} \cdot \mathrm{L}^{-1}$ (Table 4).

Table 4 shows the results of recovery for p-coumaric, ferulic and m-coumaric acids using internal and external calibrations. The extraction method recoveries obtained for phenolic acids ranged from 82 to $99 \%$, thus confirming the accuracy of the method for extraction of phenolic 
Table 4. Recovery and relative standard deviation achieved for sample and blank spiked with a mixture of acid standards for external and internal calibration.

\begin{tabular}{|c|c|c|c|c|c|c|}
\hline \multirow{2}{*}{ Compound } & \multirow{2}{*}{ Sample } & \multirow{2}{*}{ Levels of spiked concentration $\left(\mathrm{mg} \cdot \mathrm{L}^{-1}\right) \quad n=3$} & \multicolumn{2}{|c|}{ Internal calibration } & \multicolumn{2}{|c|}{ External calibration } \\
\hline & & & Mean Recovery (\%) & RSD (\%) & Mean Recovery (\%) & RSD (\%) \\
\hline \multirow{4}{*}{ p-Coumaric acid } & \multirow{3}{*}{ Sample spike } & 5.00 & 98 & 2 & 85 & 4 \\
\hline & & 7.50 & 98 & 1 & 82 & 4 \\
\hline & & 10.00 & 99 & 1 & 86 & 4 \\
\hline & Blank spike & 10.00 & 91 & 2 & 85 & 3 \\
\hline \multirow{4}{*}{ Ferulic acid } & \multirow{3}{*}{ Sample spike } & 5.00 & 88 & 2 & 85 & 1 \\
\hline & & 7.50 & 89 & 2 & 82 & 2 \\
\hline & & 10.00 & 91 & 2 & 89 & 5 \\
\hline & Blank spike & 10.00 & 83 & 1 & 85 & 3 \\
\hline \multirow{4}{*}{ m-Coumaric acid } & \multirow{3}{*}{ Sample spike } & 5.00 & 92 & 4 & 84 & 1 \\
\hline & & 7.50 & 92 & 1 & 83 & 3 \\
\hline & & 10.00 & 91 & 1 & 91 & 2 \\
\hline & Blank spike & 10.00 & 97 & 3 & 95 & 3 \\
\hline
\end{tabular}

$\mathrm{RSD}=$ relative standard deviation.

Table 5. Content (mg. $\mathrm{g}^{-1}$ dry matter) of ester-linked p-coumaric and ferulic acids in samples of Brachiaria brizantha, Cynodon dactylon, Cynodon nlemfuensis, Panicum maximum and Pennisetum purpureum.

\begin{tabular}{cccc}
\hline & & \multicolumn{2}{c}{ Content $^{\mathrm{a}} \pm$ C.I. $\left(\mathrm{mg} \cdot \mathrm{g}^{-1}\right.$ dry matter) } \\
\hline Sample & Fraction & p-CA & FA \\
Brachiaria brizantha Marandu & stem & $7.99 \pm 0.20$ & $5.41 \pm 0.25$ \\
& leaf & $5.98 \pm 0.18$ & $5.63 \pm 0.12$ \\
Cynodon dactylon cv. Florakirk & stem & $7.89 \pm 0.21$ & $4.28 \pm 0.07$ \\
& leaf & $8.60 \pm 0.41$ & $4.11 \pm 0.21$ \\
Cynodon nlemfuensis Florona & stem & $5.30 \pm 0.11$ & $4.48 \pm 0.09$ \\
& leaf & $5.82 \pm 0.13$ & $5.22 \pm 0.12$ \\
Panicum maximum Mombaça & stem & $7.74 \pm 0.33$ & $4.19 \pm 0.10$ \\
Pennisetum purpureum Anão & leaf & $4.36 \pm 0.14$ & $3.35 \pm 0.17$ \\
& stem & $0.84 \pm 0.20$ & $1.63 \pm 0.27$ \\
Pennisetum purpureum Pioneiro & leaf & $1.05 \pm 0.07$ & $3.34 \pm 0.32$ \\
& stem & $2.11 \pm 0.07$ & $2.09 \pm 0.27$ \\
\hline
\end{tabular}

p-CA = Ester-linked p-coumaric acid; FA = Ester-linked ferulic acid; ${ }^{\mathrm{a}}$ Mean \pm confidence interval $(\alpha=0.05)$ from 3 determinations.

acids. A better accuracy was obtained by internal calibration with RSD $<4 \%$ as the external calibration showed RSD $<5 \%$. However, caffeic acid is unstable and it could not be detected after the alkaline hydrolysis in this study, with no signal being detected at the retention time of this analyte (Sun et al., 2001). Shikimic acid was detected but it was not quantified in the spiked tropical forage sample since it presented co-elution with components present in the sample. For the quantification of shikimic acid, it is necessary to adjust the method, so that the accuracy was not determined for the recovery of shikimic and caffeic acids.

\subsection{Determination of Ester-Linked Phenolic Acids}

Under optimum conditions, the ultrasound bath method was applied to determine p-coumaric and ferulic acid concentrations in six tropical forage samples (in triplicate), applying an internal standard (o-coumaric acid) and a surrogate internal standard (m-coumaric acid). Table 5 shows the results obtained for p-cumaric and ferulic acids in fractions of stem and leaf of the species Brachiaria brizantha Marandu, Cynodon dactylon Florakirk, Cynodon nlemfuensis Florona, Panicum maximum Mombaça, Pennisetum purpureum Anão and Pennisetum purpureum Pioneiro. A reasonably good correlation $\left(\mathrm{r}^{2}\right.$ $=0.99-\mathrm{p}$-coumaric acid and $\mathrm{r}^{2}=0.98-$ ferulic acid) between the ultrasound bath $(2 \mathrm{~h})$ and the thermostatic bath $\left(20^{\circ} \mathrm{C}\right.$ for $\left.24 \mathrm{~h}\right)$ was found for extrac- tion. For p-coumaric acid, the confidence interval for the slope and intercept are $(0.93 \pm 0.03)$ and $(0.01 \pm 0.11) \mathrm{mg} \cdot \mathrm{g}^{-1}$ dry matter, respectively, for a $95 \%$ confidence level. For the ferulic acid the confidence interval for the slope and intercept are $(1.07 \pm 0.04)$ and $(0.01 \pm 0.16) \mathrm{mg}^{-1} \mathrm{~g}$ dry matter, respectively, for a $95 \%$ confidence level. A 
paired Student's $t$-test showed that the mean values ( $t_{\exp }<t_{\text {crit }} ; 3.52$ for p-coumaric acid and 3.38 for ferulic acid $<4.30, n=3, P=0.95$ ) did not significantly differ. Taking into account these results, no significant differences between the extraction methods were observed, strongly indicating the absence of systematic errors.

As can be seen in Table 5 for samples of Brachiaria brizantha Marandu, Cynodon nlemfuensis Florona, Pennisetum purpureum Anão and Pennisetum purpureum Pioneiro the concentration of ferulic acid is high in the leaves while the concentration of $p$-coumaric acid is high in the stem of Brachiaria brizantha Marandu and Pennisetum purpureum Pioneiro. For samples of Panicum maximum Mombaça, both acids are found at higher concentrations in the stem. For all samples except the specie Pennisetum purpureum, the concentration of $p$-coumaric acid is greater than that of ferulic acid, where the difference in concentration between the two acids is higher in the stem than in the leaf.

\section{Conclusions}

This study has demonstrated the potential use of an ultrasound bath for 120 minutes in the extraction of phenolic acids in tropical forage. This method was fast and reproducible when compared with the extraction technique using a thermostatic bath with a programmed temperature of $20^{\circ} \mathrm{C}$ for 24 hours, which is the main method reported in the literature for treatment of forage samples. The samples were quantified using an internal standard (o-coumaric acid). This method presented smaller values of LOD, LOQ and RSD for the external standard.

\section{Acknowledgements}

The authors would like to thank the FAPEMIG (Fundação de Amparo à Pesquisa do Estado de Minas Gerais), CNPq (Conselho Nacional de Desenvolvimento Cien- tífico e Tecnológico), CAPES (Coordenacão de Aper- feiçoamento de Pessoal de Nível Superior) and PRO- PESQ/UFJF (Pró-Reitoria de Pesquisa da Universi- dade Federal de Juiz de Fora) for financial support and grants Almeida, $M$. V. from the Universidade Federal de Juiz de Fora for some suggestions.

\section{Reference}

[1] R. Hatfield and R. S. Fukushima, "Can Lignin be Accurately Measured?” Crop Science, Vol. 45, No. 3, 2005, pp. 832-839. doi:10.2135/cropsci2004.0238

[2] C. D. Stalikas, "Extraction, Separation, and Detection
Methods for Phenolic Acids and Flavonoids," Journal of Separation Science, Vol. 30, No. 18, 2007, pp. 3268-3295. doi:10.1002/jssc.200700261

[3] H. G. Jung, "Forage Lignins and their Effects on Fiber Digestibility,” Agronomy Journal, Vol. 81, No. 1, 1989, pp. 33-38.

doi:10.2134/agronj1989.00021962008100010006x

[4] R. C. Sun, X. F. Sun and S. H. Zhang, "Quantitative Determination of Hydroxycinnamic Acids in Wheat, Rice, Rye, and Barley Straws, Maize Stems, Oil Palm Frond Fiber, and Fast-Growing Poplar Wood,” Journal of Agricultural and Food Chemistry, Vol. 49, No. 11, 2001, pp. 5122-5129. doi:10.1021/jf010500r

[5] C. J. F. A. Brito, A. R. Rodella and F. C. Deschamps, "Perfil Químico da Parede Celular e Suas Implicações na Digestibilidade da Brachiara Brizantha e Brachiara humidicola,” Revista Brasileira de Zootecnia, Vol. 32, No. 6, 2003, pp. 1835-1844. doi:10.1590/S1516-35982003000800005

[6] M. D. Casler and H. G. Jung, "Relationships of Fibre, Lignin, and Phenolics to in Vitro Fibre Digestibility in Three Perennial Grasses,” Animal Feed Science Technology, Vol. 125, 2006, pp. 151-161. doi:10.1016/j.anifeedsci.2005.05.015

[7] F. C. Deschamps and L. P. Ramos, "Método para a Determinação de Ácidos Fenólicos na Parede Celular de Forragens,” Revista Brasileira de Zootecnia, Vol. 31, No. 4, 2002, pp. 1634-1639. doi:10.1590/S1516-35982002000700005

[8] R. D. P. Hartley, "P-Coumaric and Ferulic Acid Components of Cell Wall of Rygrass and their Relationship with Lignin and Digestibility," Journal of the Science of Food and Agriculture, Vol. 23, No. 11, 1972, pp. 1347-1354. doi:10.1002/jsfa.2740231110

[9] H. G. Jung, "Maize Stem Tissues: Ferulate Deposition in Developing Internode Cell Walls,” Phytochemistry, Vol. 63, No. 5, 2003, pp. 543-549. doi:10.1016/S0031-9422(03)00221-8

[10] H. G. Jung and D. A. Deetz, "Cell Wall Lignification and Degradability”. In: H.G. Jung, et al. (Eds.), Forage Cell Wall Structure and Digestibility, ASA-CSSA-SSSA, Madison, USA, 1993, pp. 315-346.

[11] J. R. Robbins, "Phenolic Acids in Foods: An Overview of Analytical Methodology," Journal of Agricultural and Food Chemistry, Vol. 51, No. 10, 2003, pp. 2866-2887. doi:10.1021/jf026182t

[12] A. Carrasco-Pancorbo, A. M. Gómez-Caravaca, L. Cerretani, A. Bendini, A. Segura-Carretero and A. Fernández-Gutiérrez, "Rapid Quantification of the Phenolic fraction of Spanish Virgin Olive Oils by Capillary Electrophoresis with UV Detection,” Journal of Agricultural and Food Chemistry, Vol. 54, No. 21, 2006, pp. 79847991. doi:10.1021/jf0617925

[13] S. Ehala, M. Vaher and M. Kaljurand, "Characterization of Phenolic Profiles of Northern European Berries by Capillary Electrophoresis and Determination of their Antioxidant Activity," Journal of Agricultural and Food Chemistry, Vol. 53, No. 16, 2005, pp. 6484-6490. 
doi:10.1021/jf050397w

[14] D. L. D. Lima, A. C. Duarte and V. I. Esteves, "Optimization of Phenolic Compounds Analysis by Capillary Electrophoresis," Talanta, Vol. 72, No. 4, 2007, pp. 1404-1409. doi:10.1016/j.talanta.2007.01.049

[15] Y. Y. Peng, J. N. Ye and J. L. Kong, "Determination of Phenolic Compounds in Perilla Frutescens L. by Capillary Electrophoresis with Electrochemical Detection," Journal of Agricultural and Food Chemistry, Vol. 53, No. 21, 2005, pp. 8141-8147. doi:10.1021/jf051360e

[16] A. Canini, D. Alesiani, G. D’Arcangelo and P. Tagliatesta, "Gas Chromatography-Mass Spectrometry Analysis of Phenolic Compounds from Carica Papaya L. Leaf," Journal of Food Composition and Analysis, Vol. 20, No. 7, 2007, pp. 584-590. doi:10.1021/jf051360e

[17] Y. C. Fiamegos, C. G. Nanos, J. Vervoort and C. D. Stalikas, "Analytical Procedure for the In-Vial Derivatization-Extraction of Phenolic Acids and Flavonoids in Methanolic and Aqueous Plant Extracts Followed by Gas Chromatography with Mass-Selective Detection," Journal of Chromatography A, Vol. 1041, No. 1-2, 2004, pp. 11-18. doi:10.1016/j.chroma.2004.04.041

[18] J. H. Grabber, J. Ralph and R. D. Hatfield, "Cross-Linking of Maize Walls by Ferulate Dimerization and Incorporation into Lignin,” Journal of Agricultural and Food Chemistry, Vol. 48, No. 12, 2000, pp. 6106-6113. doi:10.1021/jf0006978

[19] M. Plessi, D. Bertelli and F. Miglietta, "Extraction and Identification by GC-MS of Phenolic Acids in Traditional Balsamic Vinegar from Modena," Journal of Food Composition and Analysis, Vol. 19, No. 1, 2006, pp. 49-54. doi:10.1016/j.jfca.2004.10.008

[20] G. Sarath, L. M. Baird, K. P. Vogel and R. B. Mitchell, "Internode Structure and Cell Wall Composition in Maturing Tillers of Switchgrass (Panicum Virgatum. L)," Bioresource Technology, Vol. 98, No. 16, 2007, pp. 2985-2992. doi:10.1016/j.biortech.2006.10.020

[21] Z. Spacil, L. Novakova and P. Solich, "Analysis of Phenolic Compounds by High Performance Liquid Chromatography and Ultra Performance Liquid Chromatography,” Talanta, Vol. 76, 2008, pp. 189-199. doi:10.1016/j.talanta.2008.02.021

[22] K. Chitindingu, A. R. Ndhlala, C. Chapano, M. A. Benhura and M. Muchuweti, "Phenolic Compound Content, Profiles and Antioxidant Activities of Amaranthus Hybridus (Pigweed), Brachiaria Brizantha (Upright Brachiaria) and Panicum Maximum (Guinea Grass),” Journal of Food Biochemistry, Vol. 31, No. 2, 2007, pp. 206-216. doi:10.1111/j.1745-4514.2007.00108.x

[23] S. Gómez-Alonso, E. García-Romero and I. HermosínGutiérrez, "HPLC Analysis of Diverse Grape and Wine Phenolics using Direct Injection and Multidetection by DAD and Fluorescence," Journal of Food Composition and Analysis, Vol. 20, No. 7, 2007, pp. 618-626. doi:10.1016/j.jfca.2007.03.002

[24] Z. L. Huang, B. W. Wang, D. H. Eaves, J. M. Shikany and R. D. Pace, "Phenolic Compound Profile of Selected
Vegetables Frequently Consumed by African Americans in the Southeast United States," Food Chemistry, Vol. 103, No. 4, 2007, pp. 1395-1402. doi:10.1016/j.foodchem.2006.10.077

[25] C. Mertz, A. Gancel, Z. Gunata, P. Alter, C. DhuiqueMayer, F. Vaillant, A. M. Perez, J. Ruales and P. Brat, "Phenolic Compounds, Carotenoids and Antioxidant Activity of Three Tropical Fruits," Journal of Food Composition and Analysis, Vol. 22, No. 5, 2009, pp. 381-387. doi:10.1016/j.jfca.2008.06.008

[26] M. A. M. Rodrigues, C. M. Guedes, J. W. Cone, A. H. van Gelder, L. M. M. Ferreira and C. A. Sequeira, "Effects of Phenolic Acid Structures on Meadow Hay Digestibility,” Animal Feed Science Technology, Vol. 136, 2007, pp. 297-311. doi:10.1016/j.anifeedsci.2006.09.009

[27] . C. I. G. Tuberoso, A. Kowalczyk, E. Sarritzu and P. Cabras, "Determination of Antioxidant Compounds and Antioxidant Activity in Commercial Oilseeds for Food Use,” Food Chemistry, Vol. 103, No. 4, 2007, pp. 14941501. doi:10.1016/j.foodchem.2006.08.014

[28] R. Al-Merey, M. S. Al-Masri and R. Bozou, “Cold Ultrasonic Acid Extraction of Copper, Lead and Zinc from Soil Samples,” Analytica Chimica Acta, Vol. 452, No. 1, 2002, pp. 143-148. doi:10.1016/S0003-2670(01)01431-3

[29] K. Ashley, R. N. Andrews, L. Cavazos and M. Demange, "Ultrasonic Extraction as a Sample Preparation Technique for Elemental Analysis by Atomic Spectrometry," Journal of Analytical Atomic Spectrometry, Vol. 16, 2001, pp. 1147-1153. doi:10.1039/b102027g

[30] A. Elik, "Ultrasound assisted pseudo-digestion of street dust samples prior to determination by atomic absorption spectrometry,” Talanta, Vol. 66, No. 4, 2005, pp. 882-888. doi:10.1016/j.talanta.2004.12.050

[31] A. Marin, C. Lopez-Gonzales and C. Barbas, "Development and Validation of Extraction Methods for Determination of Zinc and Arsenic Speciation in Soils Using Focused Ultrasound-Application to Heavy Metal Study in Mud and Soils,” Analytica Chimica Acta, Vol. 442, 2001, pp. 305-318.

[32] S. C. C. Arruda, A. P. M. Rodriguez and M. A. Z. Arruda, "Ultrasound-Assisted Extraction of $\mathrm{Ca}, \mathrm{K}$ and $\mathrm{Mg}$ from in Vitro Citrus Culture," Journal of the Brazilian Chemical Society, Vol. 14, No. 3, 2003, pp. 470-474. doi:10.1590/S0103-50532003000300023

[33] M. Liva, R. Muñoz-Olivas and C. Câmara, "Determination of Cd in Sonicate Slurries and Leachates of Biological and Environmental Materials by FI-CV-AAS," Talanta, Vol. 51, No. 2, 2000, pp. 381-387. doi:10.1016/S0039-9140(99)00292-1

[34] C. C. Nascentes, M. Korn and M. A. S. Arruda, “A Fast Ultrasound-Assisted Extraction of $\mathrm{Ca}, \mathrm{Mg}, \mathrm{Mn}$ and $\mathrm{Zn}$ from Vegetables,” Microchemical Journal, Vol. 69, No. 1, 2001, pp. 37-43. doi:10.1016/S0026-265X(00)00192-2

[35] J. C. Cypriano, M. A. C. Matos and R. C. Matos, "Ultrasound-Assisted Treatment of Palm Oil Samples for the Determination of Copper and Lead by Stripping Chronopotentiometry,” Microchemical Journal, Vol. 90, No. 1, 
2008, pp. 26-30. doi:10.1016/j.microc.2008.03.001

[36] E. A. Zakharova, V. I. Deryabina and G. B. Slepchenko, "Optimization of the Voltammetric Determination of Arsenic in Foodstuffs," Jounal of Analytical Chemistry,

\section{Abbreviations Used}

CE, capillary electrophoresis; GC-MS, gas chromatography with a mass spectrometry detector; UPLC, ultra performance liquid chromatography; HPLC, high perfor-
Vol. 60, No. 6, 2005, pp. 503-507. doi:10.1007/s10809-005-0129-3

[37] P. J. Van Soest, "Nutritional Ecology of the Ruminant”, Cornell University Press, New York, 1994. mance liquid chromatography; p-CA, ester-linked p-coumaric acid; FA, ester-linked ferulic acid; LOD, limit of detection; LOQ, limit of quantification; RSD, relative standard deviation; $\mathrm{CI}$, confidence interval. 